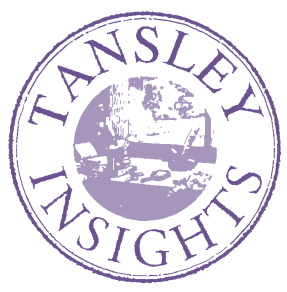

Tansley insight

\title{
Towards a holistic understanding of the beneficial interactions across the Populus microbiome
}

Authors for correspondence:

Stéphane Hacquard

Tel: +492215062322

Email: hacquard@mpipz.mpg.de

Christopher W. Schadt

Tel: +1865 5763982

Email: schadtcw@ornl.gov

Received: 3 July 2014

Accepted: 24 September 2014

\section{Stéphane Hacquard ${ }^{1}$ and Christopher W. Schadt ${ }^{2,3}$}

${ }^{1}$ Department of Plant-Microbe Interactions, Max Planck Institute for Plant Breeding Research, Cologne, Germany; ${ }^{2}$ Biosciences Division, Oak Ridge National Laboratory, Oak Ridge, TN 37831, USA; ${ }^{3}$ Department of Microbiology, University of Tennessee, Knoxville, TN 37966, USA

\section{Contents}

$\begin{array}{lllr}\text { Summary } & 1424 & \text { V. } & \begin{array}{l}\text { Toward understanding microbiome functions in a } \\ \text { community context }\end{array} \\ \text { I. Introduction } & 1424 & \text { Acknowledgements } \\ \text { II. The root endosphere and rhizosphere } & 1428 & \text { References } \\ \text { microbiome } & 1428 \\ \text { III. The phyllosphere and leaf endosphere microbiome } & 1426 & \\ \text { IV. The stem and wood microbiome } & 1427\end{array}$

New Phytologist (2015) 205: 1424-1430 doi: $10.1111 /$ nph.13133

Key words: bacteria, endophytes, fungi, microbiome, mycorrhizas, Populus, trees.

\section{Summary}

Interactions between trees and microorganisms are tremendously complex and the multispecies networks resulting from these associations have consequences for plant growth and productivity. However, a more holistic view is needed to better understand trees as ecosystems and superorganisms, where many interacting species contribute to the overall stability of the system. While much progress has been made on microbial communities associated with individual tree niches and the molecular interactions between model symbiotic partners, there is still a lack of knowledge of the multi-component interactions necessary for holistic ecosystem-level understanding. We review recent studies in Populus to emphasize the importance of such holistic efforts across the leaf, stem and rooting zones, and discuss prospects for future research in these important ecosystems.

\section{Introduction}

Populus trichocarpa was the first tree species genome sequenced (Tuskan et al., 2006), and the ability to study genetically tractable Populus trees in glasshouses and plantation agroecosytems, as well as in natural ecosystem settings, make Populus spp. powerful systems for obtaining a better understanding of plant-microbe relationships. Ectomycorrhizas and arbuscular mycorrhizas both occur within Populus (Karlinski et al., 2010), and Populus host genetic variation may influence the structure and composition of surrounding plants, soils, and overall ecosystem functions (Fischer et al., 2007, 2010, 2014). Recognizing its potential as a model system a decade ago, as sequencing of the Populus genome neared completion, Martin et al. (2004) called for the community to begin comparable efforts to sequence and study the Populus symbiont 'mesocosm'. They argued for consideration of trees as ecosystems in 
themselves and for increased understanding of their symbiotic interactions both at a holistic level and as genome-enabled model systems. In this paper, we discuss the tremendous recent progress and future potential of such efforts across the Populus ecosystem (Fig. 1).

\section{The root endosphere and rhizosphere microbiome}

\section{Diversity, structure and community-level perspectives}

A variety of recent studies have examined the root mycorrhizal components of the microbiome in Populus. A general focus of many of these studies has been contrasting the communities associated with wild-type and transgenic clones. For example, three studies (Kaldorf et al., 2002; Stefani et al., 2009; Danielsen etal., 2012) have examined both bulk soil and root fungal populations independently in plantations with different transgenic Populus lines. Each of these studies found no effects of the transgene clones on fungal communities but generally high levels of fungal diversity in association with poplar roots. A few recent whole-microbiome-level investigations in natural populations and variants of Populus deltoides have now included simultaneous examination of both bacteria and fungi in the same sampled environments and experiments, as well as for both the rhizosphere and root endosphere habitats (Gottel et al., 2011; Shakya et al., 2013; Bonito et al., 2014). In such studies, researchers have done well to begin elucidating how these different plant habitats/niches affect microbial membership, and to begin to disentangle how host, environmental, soil and geographic factors influence each of these Populus-associated community types (Shakya et al., 2013; Bonito et al., 2014). Similar results are now being obtained in a variety of host systems with the widespread application of pyrosequence-based approaches; and patterns of host specificity, host fitness effects, geographic substitution and heritability are now emerging (Lundberg et al., 2012; Peiffer et al., 2013; Bonito etal., 2014; Talbot et al., 2014; Wagner etal., 2014). These studies in Populus as well as in Arabidopsis thaliana and Zea mays systems have demonstrated that, within a host species, habitat (e.g. endosphere vs rhizosphere) and soil type, rather than host genetic background, have larger effects on the overall structure of the microbiome (Bulgarelli et al., 2012; Lundberg et al., 2012; Peiffer etal., 2013; Shakya et al., 2013; Bonito et al., 2014), but
Fig. 1 Understanding of both the diversity of plant-associated microbial habitats and their functioning has greatly increased with sequencing-based analyses. These analyses have provided striking insights into the reductionist functioning of symbiotic partners as well as a more holistic understanding of microbial community interactions.

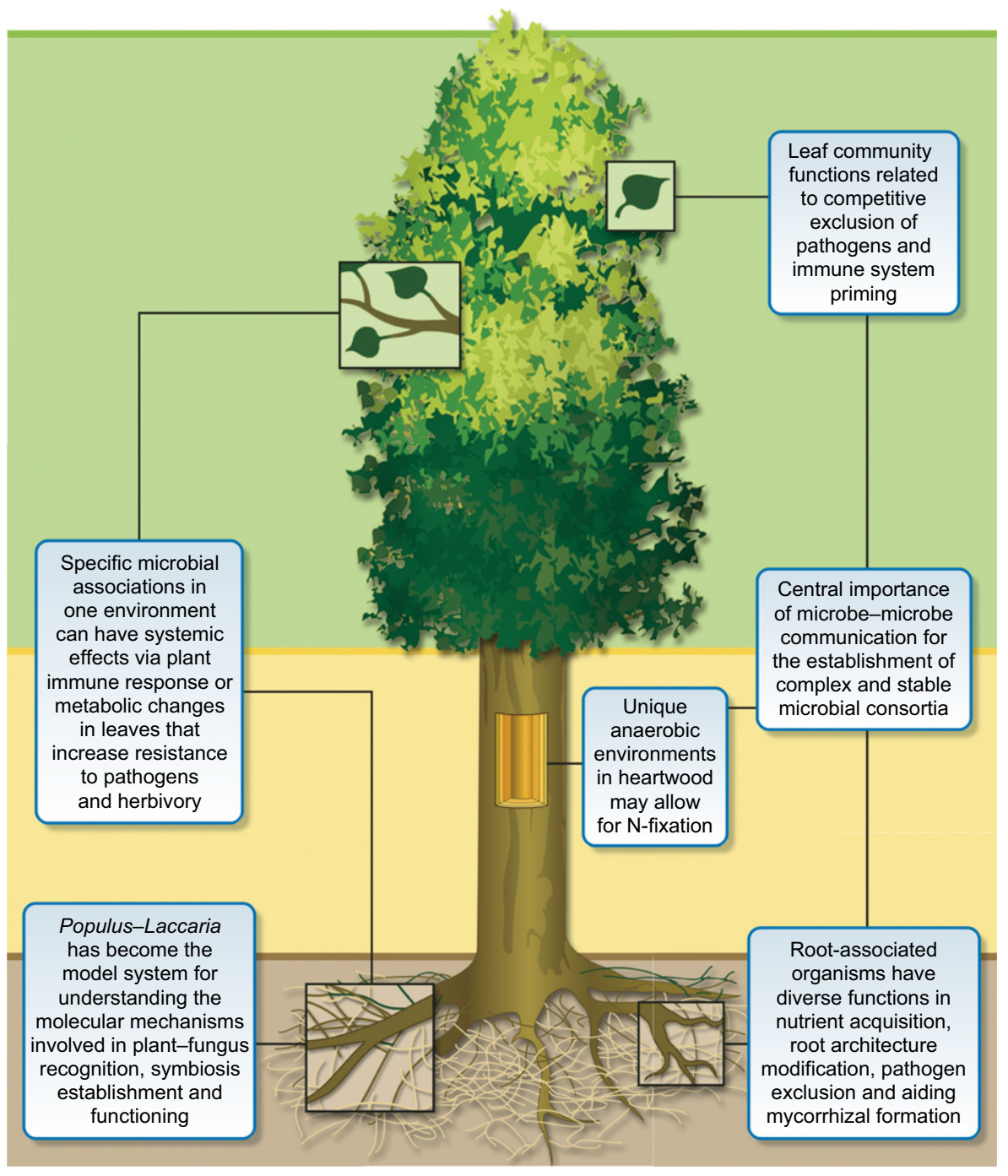


the balance of the effects of genetic and soil factors within host habitats on bacteria and fungi is less clear. Evidence from natural systems, soil inoculum assays, and pairwise colonization assays suggests that, perhaps as a consequence of their often weak ectomycorrhizal (ECM) nature, root endophytic organisms may be particularly important for Populus trees compared with other ECM trees and result in higher levels of microbiome diversity due to increased niche space (Bonito et al., 2014; Tshaplinski et al., 2014)

A systematic understanding of how overall rhizosphere communities and their members differ from or complement each other in terms of functioning within the plant, across the plant and between tree taxa is still lacking. However, meta-analysis and synthesis studies that collectively analyse and compare such communities should now be possible with the widespread adoption of community databasing and standards in microbiome sequence studies (Yilmaz et al., 2011).

\section{Specific interactions, mechanisms and functions}

While the basic functions of mycrorrhizas in terms of nutrient and water acquisition are known, the specific detailed signaling mechanisms involved in the formation and functioning of both ECM and arbuscular mycorrhizal (AM) symbiosis have remained elusive. Genome-enabled studies using the Laccaria-Populus system have led to several insights in this area and suggest that mutual signaling mechanisms allow recognition, initiation and reorganization of the symbiotic root organ. Particularly surprising has been the role that small secreted proteins play. MycorrhizalInduced Small Secreted Protein 7 (MiSSP7) production in Laccaria bicolor appears to be induced by unknown exudates from Populus roots (Plett et al., 2011; Plett \& Martin, 2012). MiSSP7 in turn migrates to the plant nuclei and alters the hormonal balance of the plant defense system, allowing mycorrhizal formation to proceed (Plett et al., 2014). However, these detailed patterns of recognition may be species specific even within Populus host species. While the above recognition mechanism is effective in $P$. trichocarpa, in $P$. deltoides the host defensive system is not effectively suppressed by Laccaria and ECM formation does not proceed (Tshaplinski et al., 2014). Future investigations will need to further explore the phylogenetic distributions of such signaling interactions both with closely related model species and across diverse host-fungal systems, to gain insight into the varying patterns of species specificity and generalist phenomena. The recent completion of the genome sequence of the AM fungus Rhizophagus irregularis (ex Glomus) (Tisserant etal., 2013) may similarly provide clues necessary to accelerate such research into the functioning of AM systems. Additionally, the use of Populus as a host for such studies, with its ability to form both AM and ECM symbioses, should provide insight into the largely unanswered questions of why and under what conditions Populus forms both types of symbiosis. While there appear to be both genetic and environmental influences on alternation between the two symbiosis modes in Populus (Lodge, 1989; Gehring et al., 2006; Karlinski et al., 2010), the detailed mechanisms and in planta functioning of such dual symbioses are still unclear.
Beyond mycorrhizal symbionts, Populus is also host to a variety of bacterial and fungal rhizosphere partners and root endophytes. Indeed, several studies have shown putative mycorrhizal fungal taxa on and within Populus to be outnumbered by other root endopyhtic fungi such as Atractiella, Phialophora, Illyonectria and Mortierella spp. (Gottel et al., 2011; Shakya et al., 2013; Bonito et al., 2014). Therefore, elucidating the full potential of microbiome effects on tree growth, health and reproduction also depends on understanding these often neglected plant-microbe interactions. Bacterial endophytes have been shown to have varying functions in altering root branching/allocation patterns through production of plant hormone precursors such as indole acetic acid (IAA) (Dimkpa et al., 2012; Weyens et al., 2012), transformation and mobilization of nutrients such as nitrogen $(\mathrm{N})$ and phosphorus (Browne et al., 2009), enhanced mycorrhizal formation (e.g. mycorrhizal helper bacteria; Deveau etal., 2007; Zhao et al., 2014), and aiding in pathogen resistance through competitive exclusion or production of antibiotics (Lugtenberg et al., 2001) or priming of plant immune responses (Weston et al., 2012). None of these effects, however, seem to be mutually exclusive, as various isolates of even a single genus or species complex such as Pseudomonas fluorescens seem capable of many of these functions, as well as pathogenic effects (Weston et al., 2012).

\section{The phyllosphere and leaf endosphere microbiome}

\section{Diversity, structure and community-level perspectives}

The interaction between plants and their associated phyllosphere microbial communities has received increasing attention during the last decade (Vorholt, 2012). Microbial diversity and community structure have been described in several woody plant species (Jumpponen \& Jones, 2009; Redford et al., 2010; Finkel et al., 2011; Cordier et al., 2012; Coince et al., 2014) but our knowledge of the structure of both fungal and bacterial communities associated with poplar leaves remains fragmented. Culture-independent approaches indicate that host genotype is an important factor structuring both fungal and bacterial communities in poplar leaves and suggest that phyllosphere microbial community assemblage is at least partially determined by host genetic variation (Ulrich et al., 2008; Bálint et al., 2013). Consistent with a possible enrichment of infrequent fungal species in the phyllosphere community of trees (Unterseher et al., 2011), the poplar leaf fungal community was found to be very diverse and is represented by a few abundant taxa and numerous rare taxa (Bálint et al., 2013). Although the phyllosphere bacterial community of poplar can vary over the growing season (Redford \& Fierer, 2009), the general structure, consisting of the dominance of Proteobacteria, Actinobacteria and Bacteroidetes, is not strikingly different from the pattern found for other plant species including angiosperms, grasses and $A$. thaliana, suggesting an overall conserved structure that is defined by relatively few bacterial phyla (Ulrich et al., 2008; Redford et al., 2010; Bodenhausen et al., 2013; Bulgarelli et al., 2013).

Integrated approaches are needed to understand the processes responsible for determining the structure and assembly rules of phyllosphere communities. One approach recently used various 
A. thaliana mutants and revealed that cuticular wax and ethylene can significantly affect the community composition of phyllosphere bacteria (Reisberg et al., 2013; Bodenhausen et al., 2014). In addition, a comprehensive survey of the topographical distribution of fungi and bacteria across various organs of individual tree species is still needed to better understand the tissue-type specificity of microbial community assemblages. Finally, recent studies indicate that, in addition to the host plant, synergistic, beneficial and antagonistic interactions among microbes may have tremendous impacts on microbial community structure and function in both the phyllosphere and the rhizosphere (Frey-Klett etal., 2011; Kemen, 2014). Therefore, understanding of both leaf- and rootassociated microbiota structure also relies on the understanding of more complex interactions, where fungal, oomycete and bacterial communities are not considered as separate entities but as active drivers of overall microbial community assemblages.

\section{Specific interactions, mechanisms and functions}

Although the structure and diversity of bacterial and fungal communities associated with the leaves of woody plants species have been reported, the associated functions remain poorly characterized. It has been recently shown that different fungal endophytes isolated from poplar leaves naturally infected by the rust fungus Melampsora can dramatically reduce rust symptom severity under laboratory conditions and significantly contribute to quantitative resistance to the foliar rust pathogen (Raghavendra \& Newcombe, 2013). Interestingly, however, some of these same endophytes do not show similar effects against other Populus pathogens (Busby et al., 2013). Strikingly, root-associated microbiota members are also known to induce systemic responses in leaves, resulting in increased resistance to plant pathogens (Weston et al., 2012; Kurth et al., 2014) and herbivory (Badri et al., 2013). These selected examples illustrate why a more holistic understanding of plant disease is needed to better understand beneficial interactions across the plant microbiome (Van der Putten et al., 2001).

\section{The stem and wood microbiome}

While the rhizosphere and phyllosphere have received considerably more attention as microbial habitats, there is increasing evidence that microorganisms inhabiting the heartwood tissues within some woody plants such as Populus may have great importance that has to date been unfairly neglected (Knoth et al., 2014). In Populus, many conifers, and other important forest tree species, the heartwood has no living parenchyma cells and only saturated xylem tissues (e.g. wetwood) that can produce anaerobic conditions favoring fermentation or even methanogenesis (Zeikus \& Henning, 1974). Prior reports suggested that communities associated with both $P$. trichocarpa and $P$. deltoides also have the potential to fix $\mathrm{N}$ in these niches, as evidenced by acetylene reduction assays (Schink et al., 1981; Kamp, 1986). Numerous diazotrophic bacteria have been isolated from such habitats. Cross-inoculation experiments have shown broad growth-promoting effects of these organisms on other plant species, including nonwoody plants such as rice (Oryza sativa) and maize (Govindarajan et al., 2008; Knoth et al., 2013), and isolates of bacterial genera, including Burkholderia, Rhizobium, Enterobacter and Paenibacillus (Doty et al., 2009; Scherling et al., 2009) often show the ability to reduce $\mathrm{N}_{2}$ in pure cultures outside the host. Isotopic studies using ${ }^{15} \mathrm{~N}$ in $P$. trichocarpa inoculated with consortia of bacteria species showed signatures indicative of active fixation and that wetwood may account for up to $65 \%$ of the $\mathrm{N}$ in leaf tissues (Knoth et al., 2014). Culturable fungal endophytes have also recently been examined within the woody tissues of branches of Populusangustifolia (Lamit etal., 2014). While functional aspects have not been examined, it is clear from this first work that even the simple communities within woody tissues can be influenced by tree genotype. Additionally, many of the fungal genera identified seem to overlap with those commonly found within leaf and root endophyte habitats.

Despite indications of the great importance of heartwood habitat, all knowledge to date comes from studies of individual bacterial and fungal isolates, and a few studies of defined consortia. Interestingly, there is some indication that these mixed consortia of organisms show differing effects and sometimes more robust growth promotion (Knoth et al., 2013, 2014), and this has been speculated to be attributable to increased niche colonization. However, microbiome, metagenome, or even Sanger sequencingbased surveys of microbial populations within woody habitats are lacking. In planta localization of $\mathrm{N}$-fixing bacteria has yet to be visualized via fluorescence in situ hybridization (FISH) or other methods. The use of combinations of advanced microscopy and isotopically resolved mass spectroscopy techniques (e.g. NanoSIMS), could potentially be very useful (Pett-Ridge \& Weber, 2012). Given these tantalizing results, and the potential importance of alternative mechanisms of $\mathrm{N}$ fixation, microbiome studies of heartwood should be prioritized.

\section{Toward understanding microbiome functions in a community context}

Interactions between trees and their associated microbial communities are tremendously complex and the resulting multiorganismal networks have central roles in plant growth and productivity (Bonfante \& Anca, 2009). A more holistic view of plant health and disease is needed to better understand these 'superorganisms', in which interacting species are thought to play a role in the overall stability of the system. Similar to the human microbiota, disruption of the homeostasis between plants and their associated fungal and bacterial communities may alter the stability of the system, with potential impacts on host fitness (Frey-Klett et al., 2011). Although culture-independent methods have contributed tremendously to our understanding of tree-associated fungal and bacterial community structures, the study of microbiota functions in a community context remains challenging because of the inherent noise of plantassociated microbial communities seen in nature. One reductionist approach to overcome this limitation is the use of reciprocal transplantation experiments, where plants are moved from one environment to another environment or grown with the same soil inoculum under controlled conditions. Such an approach has been recently used to decipher the role of soil biota in plant adaptation, 
revealing that plants are not limited to adapt or migrate, but perhaps utilize microbial consortia to adapt to a novel or disturbed environment (Lau \& Lennon, 2012; Gundale et al., 2014). Alternatively, extraction of presumably intact communities from different soil types has also been used to investigate how distinct environmental microbiomes can alter plant flowering phenology, and represents a promising approach in the search for microbial consortia that alter biological characteristics of interest (Wagner et al., 2014). Finally, extensive reference culture collections of plant-associated fungal and bacterial stains isolated from model plant species are currently being established and will provide in the near future an inestimable resource for assembling taxonomically defined microbial communities with increasing complexity (Brown et al., 2012; Lebeis etal., 2012; De Roy etal., 2014). The modularity of synthetic communities has already provided new insights into the structure and function of plant-associated microbiota (Bodenhausen et al., 2014; Knoth et al., 2014; Rolli et al., 2014). The assembly of more complex defined microcosms that better mimic environmental microbiomes will aid in (1) understanding the dynamics of host colonization by complex root- and leaf-associated microbial communities, (2) deciphering the contribution of plant-microbe and microbe-microbe interactions in the structuring of microbial consortia, and (3) identifying complex microcosms that promote host fitness when exposed to biotic or abiotic stressors. While studies in Populus have been informative in their own right, they will become of increasing interest as a comparison with new models such as Eucalyptus, Pinus, and others being developed now and in the future.

\section{Acknowledgements}

The authors thank B. Hopwood and K. Christen for assistance with the figure graphics, as well as M. Robeson, C. Hamilton, F. Martin and three peer reviewers for critical insights. S.H. is supported by the Max Planck Society and the European Research Council. C.W.S. is supported by the Genomic Science Program, US Department of Energy, as part of the Plant Microbe Interfaces Scientific Focus Area (http://pmi.ornl.gov). Oak Ridge National Laboratory is managed by UT-Battelle LLC, for the US Department of Energy under contract DEAC05-00OR22725.

\section{References}

Badri DV, Zolla G, Bakker MG, Manter DK, Vivanco JM. 2013. Potential impact of soil microbiomes on the leaf metabolome and on herbivore feeding behavior. New Phytologist 198: 264-273.

Bálint M, Tiffin P, Hallström B, O’Hara RB, Olson MS, Fankhauser JD, Piepenbring M, Schmitt I. 2013. Host genotype shapes the foliar fungal microbiome of balsam poplar (Populus balsamifera). PLoS ONE 8: e53987.

Bodenhausen N, Bortfeld-Miller M, Ackermann M, Vorholt JA. 2014. A synthetic community approach reveals plant genotypes affecting the phyllosphere microbiota. PLoS Genetics 10: e1004283.

Bodenhausen N, Horton MW, Bergelson J. 2013. Bacterial communities associated with the leaves and the roots of Arabidopsis thaliana. PLoS ONE 8: e56329.

Bonfante P, Anca IA. 2009. Plants, mycorrhizal fungi, and bacteria: a network of interactions. Annual Review of Microbiology 63: 363-383.
Bonito G, Reynolds H, Robeson M, Nelson J, Hodkinson B, Tuskan G, Schadt CW, Vilgalys R. 2014. Plant host and soil origin influence fungal and bacterial assemblages in the roots of woody plants. Molecular Ecology 23: 3356-3370.

Brown SD, Utturkar SM, Klingeman DM, Johnson CM, Stanton M, Land ML, Lu TY, Schadt CW, Doktycz MJ, Pelletier DA. 2012. Twenty-one Pseudomonas genomes and 19 genomes from other diverse bacteria isolated from the rhizosphere and endosphere of Populus deltoides. Journal of Bacteriology 194: 5991-5993.

Browne P, Rice O, Miller SH, Burke J, Dowling DN, Morrissey JP, O'Gara F. 2009. Superior inorganic phosphate solubilization is linked to phylogeny within the Pseudomonas fluorescens complex. Applied Soil Ecology 43: 131-138.

Bulgarelli D, Rott M, Schlaeppi K, Ver Loren van Themaat E, Ahmadinejad N, Assenza F, Rauf P, Huettel B, Reinhardt R, Schmelzer E et al. 2012. Revealing structure and assembly cues for Arabidopsis root-inhabiting bacterial microbiota. Nature 488: 91-95.

Bulgarelli D, Schlaeppi K, Spaepen S, Ver Loren van Themaat E, Schulze-Lefert P. 2013. Structure and functions of the bacterial microbiota of plants. Annual Review of Plant Biology 64: 807-838.

Busby PE, Zimmerman N, Weston DJ, Jawdy SS, Houbraken J, Newcombe G. 2013. Leaf endophytes and Populus genotype affect severity of damage from the necrotrophic leaf pathogen, Drepanopeziza populi. Ecosphere 4: 125.

Coince A, Cordier T, Lengellé J, Defossez E, Vacher C, Robin C, Buée M, Marçais B. 2014. Leaf and root-associated fungal assemblages do not follow similar elevational diversity patterns. PLoS ONE 9: e100668.

Cordier T, Robin C, CapdevielleX, Fabreguettes O, Desprez-Loustau ML, Vacher C. 2012. The composition of phyllosphere fungal assemblages of European beech (Fagus sylvatica) varies significantly along an elevation gradient. New Phytologist 196: 510-519.

Danielsen L, Thürmer A, Meinicke P, Buee M, Morin E, Martin F, Pilate G, Daniel R, Polle A, Reich M. 2012. Fungal soil communities in a young transgenic poplar plantation form a rich reservoir for fungal root communities. Ecology and Evolution 2: 1935-1948.

De Roy K, Marzorati M, Van den Abbeele P, Van de Wiele T, Boon N. 2014. Synthetic microbial ecosystems: an exciting tool to understand and apply microbial communities. Environmental Microbiology 16: 1472 1781

Deveau A, Palin B, Delaruelle C, Peter M, Kohler A, Pierrat JC, Sarniguet A, Garbaye J, Martin F, Frey-Klett P. 2007. The mycorrhiza helper Pseudomonas fluorescens BBc6R8 has a specific priming effect on the growth, morphology and gene expression of the ectomycorrhizal fungus Laccaria bicolor S238N. New Phytologist 175: 743-755.

Dimkpa CO, Zeng J, McLean JE, Britt DW, Zhan J, Anderson AJ. 2012. Production of indole-3-acetic acid via the indole-3-acetamide pathway in the plant-beneficial bacterium Pseudomonas chlororaphis $\mathrm{O} 6$ is inhibited by $\mathrm{ZnO}$ nanoparticles but enhanced by $\mathrm{CuO}$ nanoparticles. Applied and Environmental Microbiology 78: 1404-1410.

Doty SL, Oakley B, Xin G, Kang JW, Singleton G, Khan Z, Vajzovic A, Staley JT. 2009. Diazotrophic endophytes of native black cottonwood and willow. Symbiosis 47: 23-33.

Finkel OM, Burch AY, Lindow SE, Post AF, Belkin S. 2011. Geographical location determines the population structure in phyllosphere microbial communities of a salt-excreting desert tree. Applied and Environmental Microbiology 77: 76477655.

Fischer DG, Chapman SK, Classen AT, Gehring CA, Grady KC, Schweitzer JA, Whitham TG. 2014. Plant genetic effects on soils under climate change. Plant and Soil 379: 1-19.

Fischer DG, Hart SC, LeRoy CJ, Whitham TG. 2007. Variation in belowground carbon fluxes along a Populus hybridization gradient. New Phytologist 176: 415-425.

Fischer DG, Hart S, Schweitzer J, Selmants P, Whitham T. 2010. Soil nitrogen availability varies with plant genetics across diverse river drainages. Plant and Soil 331: 391-400.

Frey-Klett P, Burlinson P, Deveau A, Barret M, Tarkka M, Sarniguet A. 2011. Bacterial-fungal interactions: hyphens between agricultural, clinical, environmental, and food microbiologists. Microbiology and Molecular Biology Reviews 75: 583-609. 
Gehring CA, Mueller C, Whitham TG. 2006. Environmental and genetic effects on the formation of ectomycorrhizal and arbuscular mycorrhizal associations in cottonwoods. Oecologia 149: 158-164.

Gottel NR, Castro HF, Kerley M, Yang ZK, Pelletier DA, Podar M, Karpinets T, Uberbacher E, Tuskan GA, Vilgalys $\mathrm{R}$ et al. 2011. Populus deltoides roots harbor distinct microbial communities within the endosphere and rhizosphere across contrasting soil types. Applied and Environmental Microbiology 77: 5934-5944.

Govindarajan M, Balandreau J, Kwon SW, Weon HY, Lakshminarasimhan C. 2008. Effects of the inoculation of Burkholderia vietnamensis and related endophytic diazotrophic bacteria on grain yield of rice. Microbial Ecology 55: 21-37.

Gundale MJ, Kardol P, Nilsson MC, Nilsson U, Lucas RW, Wardle DA. 2014. Interactions with soil biota shift from negative to positive when a tree species is moved outside its native range. New Phytologist 202: 415-421.

Jumpponen A, Jones KL. 2009. Massively parallel 454 sequencing indicates hyperdiverse fungal communities in temperate Quercus macrocarpa phyllosphere. New Phytologist 184: 438-448.

Kaldorf M, Fladung M, Muhs HJ, Buscot F. 2002. Mycorrhizal colonization of transgenic aspen in a field trial. Planta 214: 653-660.

Kamp BJ. 1986. Nitrogen fixation in cottonwood wetwood. Canadian Journal of Forest Research 16: 1118-1120.

Karlinski L, Rudawska M, Kieliszweska-Rokicka B, Leski T. 2010. Relationship between genotype and soil environment during colonization of poplar roots by mycorrhizal and endophytic fungi. Mycorrhiza 20: 315-324.

Kemen E. 2014. Microbe-microbe interactions determine oomycete and fungal host colonization. Current Opinion in Plant Biology 20: 75-81.

Knoth JL, Kim S-H, Ettl GJ, Doty SL. 2013. Effects of cross host species inoculation of nitrogen-fixing endophytes on growth and leaf physiology of maize. GCB Bioenergy 5: 408-418.

Knoth JL, Kim SH, Ettl GJ, Doty SL. 2014. Biological nitrogen fixation and biomass accumulation within poplar clones as a result of inoculations with diazotrophic endophyte consortia. New Phytologist 201: 599-609.

Kurth F, Mailänder S, Bönn M, Feldhahn L, Herrmann S, Große I, Buscot F, Schrey SD, Tarkka MT. 2014. Streptomyces-induced resistance against oak powdery mildew involves host plant responses in defence, photosynthesis and secondary metabolism pathways. Molecular Plant-Microbe Interactions 27: 891-900.

Lamit LJ, Lau MK, Sthultz M, Wooley SC, Whitham TG, Gehring CA. 2014. Tree genotype and genetically based growth traits structure twig endophyte communities. American Journal of Botany 101: 467-478.

Lau JA, Lennon JT. 2012. Rapid responses of soil microorganisms improve plant fitness in novel environments. Proceedings of the National Academy of Sciences, USA 109: 14058-14062.

Lebeis SL, Rott M, Dangl JL, Schulze-Lefert P. 2012. Culturing a plant microbiome community at the cross-Rhodes. New Phytologist 196: 341-344.

Lodge DJ. 1989. The influence of soil moisture and flooding on formation of VA-endo- and ectomycorrhizae in Populus and Salix. Plant and Soil 117: 243-253.

Lugtenberg BJ, Dekkers L, Bloemberg GV. 2001. Molecular determinants of rhizosphere colonization by Pseudomonas. Annual Review of Phytopathology 39: 461-490.

Lundberg DS, Lebeis SL, Herrera-Paredes S, Yourstone S, Gehring J, Malfatti S, Tremblay J, Engelbrekston A, Kunin V, Glavina del Rio T et al. 2012. Defining the core Arabidopsis thaliana root microbiome. Nature 488: 86-90.

Martin F, Tuskan GA, DiFazio SP, Lammers P, Newcombe G, Podila GK. 2004. Symbiotic sequencing for the Populus mesocosm. New Phytologist 161: 330-335.

Peiffer JA, Spor A, Jin Z, Koren O, Tringe SG, Dangl JL, Buckler ES, Ley RE. 2013. Diversity and heritability of the maize rhizosphere microbiome under field conditions. Proceedings of the National Academy of Sciences, USA 110: 6548-6553.

Pett-Ridge J, Weber PK. 2012. NanoSIP: NanoSIMS applications for microbial biology. Methods in Molecular Biology 881: 375-408.

Plett JM, Daguerre Y, Wittulsky S, Vayssières A, Deveau A, Melton SJ et al. 2014. Effector MiSSP7 of the mutualistic fungus Laccaria bicolor stabilizes the Populus JAZ6 protein and represses jasmonic acid (JA) responsive genes. Proceedings of the National Academy of Sciences, USA 111: 8299-8304.
Plett JM, Kemppainen M, Kale SD, Kohler A, Legué V, Brun A, Tyler BM, Pardo AG, Martin F. 2011. A secreted effector protein of Laccaria bicolor is required for symbiosis development. Current Biology 21: 1197-1230.

Plett JM, Martin F. 2012. Poplar root exudates contain compounds that induce expression of MiSSP7 in Laccaria bicolor. Plant Signaling \& Behavior 7: 12-15.

Raghavendra AK, Newcombe G. 2013. The contribution of foliar endophytes to quantitative resistance to Melampsora rust. New Phytologist 197: 909-918.

Redford AJ, Bowers RM, Knight R, Linhart Y, Fierer N. 2010. The ecology of the phyllosphere: geographic and phylogenetic variability in the distribution of bacteria on tree leaves. Environmental Microbiology 12: 2885-2893.

Redford AJ, Fierer N. 2009. Bacterial succession on the leaf surface: a novel system for studying successional dynamics. Microbial Ecology 58: 189-198.

Reisberg EE, Hildebrandt U, Riederer M, Hentschel U. 2013. Distinct phyllosphere bacterial communities on Arabidopsis wax mutant leaves. PLoS ONE 8: e78613.

Rolli E, Marasco R, Vigani G, Ettoumi B, Mapelli F, Deangelis ML, Gandolfi C, Casati E, Previtali F, Gerbino R et al. 2014. Improved plant resistance to drought is promoted by the root-associated microbiome as a water stress-dependent trait. Environmental Microbiology. doi: 10.1111/1462-2920.12439.

Scherling C, Ulrich K, Ewald D, Weckwerth W. 2009. A metabolic signature of the beneficial interaction of the endophyte Paenibacillus sp. isolate and in vitro-grown poplar plants revealed by metabolomics. Molecular Plant-Microbe Interactions 22: 1032-1037.

Schink B, Ward JC, Zeikus JG. 1981. Microbiology of wetwood: role of anaerobic bacterial populations in living trees. Journal of General Microbiology 123: 313-322.

Shakya M, Gottel N, Castro H, Yang ZK, Gunter L, Labbe J, Muchero W, Bonito G, Vilgalys R, Tuskan G et al. 2013. A multifactor analysis of fungal and bacterial community structure in the root microbiome of mature Populus deltoides trees. PLoS ONE 8: e76382.

Stefani FO, Moncalvo JM, Séguin A, Bérubé JA, Hamelin RC. 2009. Impact of an 8 -year-old transgenic poplar plantation on the ectomycorrhizal fungal community. Applied and Environmental Microbiology 75: 7527-7536.

Talbot JM, Bruns TD, Taylor JW, Smith DP, Branco S, Glassman SI, Erlandson S, Vilgalys R, Liao H-L, Smith ME et al. 2014. Endemism and functional convergence across the North American soil mycobiome. Proceedings of the National Academy of Sciences, USA 111: 6341-6346.

Tisserant E, Malbreil M, Kuo A, Kohler A, Symeonidi A, Balestrini R, Charron P, Duensing N, Frei dit Frey N, Gianinazzi-Pearson V et al. 2013. Genome of an arbuscular mycorrhizal fungus provides insight into the oldest plant symbiosis. Proceedings of the National Academy of Sciences, USA 110: 20117-20122.

Tshaplinski TJ, Plett JM, Engle NL, Deveau A, Cushman KC, Martin MZ, Doktycz MJ, Tuskan GA, Brun A, Kohler A et al. 2014. Populus trichocarpa and Populus deltoides exhibit different metabolomic responses to colonization by the symbiotic fungus Laccaria bicolor. Molecular Plant-Microbe Interactions 27: 546-556.

Tuskan GA, Difazio S, Jansson S, Bohlmann J, Grigoriev I, et al. 2006. The genome of black cottonwood, Populus trichocarpa (Torr. \& Gray). Science 313: 1596-1604.

Ulrich K, Ulrich A, Ewald D. 2008. Diversity of endophytic bacterial communities in poplar grown under field conditions. FEMS Microbiology Ecology 63: 169-180.

Unterseher M, Jumpponen A, Opik M, Tedersoo L, Moora M, Dormann CF, Schnittler M. 2011. Species abundance distributions and richness estimations in fungal metagenomics - lessons learned from community ecology. Molecular Ecology 20: 275-285.

Van der Putten WH, Vet LEM, Harvey JA, Wäckers FL. 2001. Linking above- and belowground multitrophic interactions of plants, herbivores, pathogens, and their antagonists. Trends in Ecology and Evolution 16: 547-554.

Vorholt JA. 2012. Microbial life in the phyllosphere. Nature Reviews Microbiology 10: 828-840.

Wagner MR, Lundberg DS, Coleman-Derr D, Tringe SG, Dangl JL, Mitchell-Olds T. 2014. Natural soil microbes alter flowering phenology and the intensity of selection on flowering time in a wild Arabidopsis relative. Ecology Letters 17: 717-726.

Weston DJ, Pelletier DA, Morrell-Falvey JL, Tschaplinski TJ, Jawdy SJ, Lu TY, Allen SM, Karve A, Melton SJ, Martin MZ et al. 2012. Pseudomonas fluorescens induces strain-dependent and strain-independent host plant responses in defense 
networks, primary metabolism, photosynthesis and fitness. Molecular PlantMicrobe Interactions 25: 765-778.

Weyens N, Boulet J, Adriaensen D, Timmermans JP, Prinsen E, Van Oevelen S, Smeets K, van der Lelie D, Taghavi S, Vangronsveld J. 2012. Contrasting colonization and plant growth promoting capacity between wild type and a gfp-derative of the endophyte Pseudomonas putida W619 in hybrid poplar. Plant and Soil 356: 217-230.

Yilmaz P, Kottmann R, Field D, Knight R, Cole JR, Amaral-Zettler L, Gilbert JA, Karsch-Mizrachi I, Johnston A, Cochrane G et al. 2011. Minimum information about a marker gene sequence (MIMARKS) and minimum information about any (x) sequence (MIxS) specifications. Nature Biotechnology 29: 415-420.

Zeikus JG, Henning DL. 1974. Methane formation in living trees: a microbial origin. Science 184: 1181-1183.

Zhao L, Wu ZQ, Ye JR, Li H, Li GE. 2014. Isolation and characterization of a mycorrhiza helper bacterium from rhizosphere soils of poplar stands. Biology and Fertility of Soils 50: 593-601.

\section{About New Phytologist}

- New Phytologist is an electronic (online-only) journal owned by the New Phytologist Trust, a not-for-profit organization dedicated to the promotion of plant science, facilitating projects from symposia to free access for our Tansley reviews.

- Regular papers, Letters, Research reviews, Rapid reports and both Modelling/Theory and Methods papers are encouraged. We are committed to rapid processing, from online submission through to publication 'as ready' via Early View - our average time to decision is $<26$ days. There are no page or colour charges and a PDF version will be provided for each article.

- The journal is available online at Wiley Online Library. Visit www.newphytologist.com to search the articles and register for table of contents email alerts.

- If you have any questions, do get in touch with Central Office (np-centraloffice@lancaster.ac.uk) or, if it is more convenient, our USA Office (np-usaoffice@lancaster.ac.uk)

- For submission instructions, subscription and all the latest information visit www.newphytologist.com 